\title{
2 胸腹部大動脈瘤の外科治療とその問題点
}

\author{
岡山大学 第 2 外科

\section{内田發三清水康廣妹尾嘉昌 寺本滋}

\section{はじめに}

胸腹部大動脈瘤は比較的稀な疾患であるが，最近本邦 でもその報告例が増加しつつある. 本症の外科治療上の 問題点は，1）到達方法，2）再建方法，3）補助手 段，4) 対麻痺の予防手段，5）腎保護などである。わ れわれが経験した 5 症例を報告し，これらの問題点につ いて若干の考察を加宎たい.

\section{対 象}

過去 5 年間に経験した胸腹部大動脈瘤の手術症例は 5 例で，Crawford の病型分類 ${ }^{1)}$ 以従党ば I 型 1 例， III 型 2 例， $\mathrm{N}$ 型 2 例である（表1）。これらの平均年齢は 53 歳，性別はすべて男性であり，その成因は動脈硬化性 4 例，解離性 1 例である（表 2 )。 5 例のうち 3 例は背 部 痛，心窝部痛などの自覚症状を有し，残りの 2 例は胸部 異常陰影を指摘されたものである。

\section{手術方法および成績（表 2 ）}

病変への到達方法はすべて spiral opening 法2)を応用 した，症例 $1 \sim 4$ の 4 例は開胸・開腹により到達し，一 期的手術を施行し，症例 5 は二期的手術を行った。すな わち， III 型の症例 5 は最初開胸により胸部下行大動脈置 換術を行い，その 3 力月後に胸腹部大動脈置換術を行っ た。本例の腹部大動脈は後腹膜到達法により露出した。

血行再建方法は, I 型の症例 1 では腹腔動脈を温存し, III型の症例 2 でも末梢側の瘤壁とともに腹腔動脈を残存 させ，胸腹部大動脈置換を行った， $\mathrm{N}$ 型の症例 3 は $\mathrm{T}_{10}$ の部位に和いて entry を縫合閉鎖し，左腎動脈の開空術 を行いつつ腹部大動脈を置換 し， $\mathbb{N}$ 型の症例 4 では Etheredge 法により下腸間動脈以外の腹部内臟動脈を すべて再建しつつ胸腹部大動脈置換術を施行した．III型 の症例 5 は先に述べたごとく二期的手術を行ったが，胸 腹部大動脈置換は DeBakey 法を応用し, $\mathbf{T}_{10}$ 肋間動脈 を温存し，腹腔動脈および上腸間動脈を再建した。

補助手段としては症例 5 の二期手術以外ではすべて人 工血管による一時的バイパス法を応用した，
表 1 Thoracoabdominal and abdominal aortic aneurysms involving celiac, superior mesenteric, and renal arteries classified according to extent of disease. (Crawford, E.S.)

\begin{tabular}{clc}
\hline Group & \multicolumn{1}{c}{ Involvement } & No. Cases \\
\hline I & $\begin{array}{c}\text { Thoracic and abdominal aorta } \\
\text { without vessels } \\
\text { Entire aorta } \\
\text { II }\end{array}$ & 1 \\
III & $\begin{array}{l}\text { Most descending thoracic and } \\
\text { abdominal aorta with vessels } \\
\text { Distal thoracic and abdominal } \\
\text { aorta with vessels }\end{array}$ & 2 \\
N & $\begin{array}{l}\text { Abdominal aorta with vessels } \\
\text { Abdominal aorta with renal arteries }\end{array}$ \\
V & Total & 2 \\
\hline (1979 1984 O.U.M.)
\end{tabular}

対麻痺の予防として，基本的には一時的バイパスによ り遮断末梢の動脈圧を維持し, 内藏動脈の血行をはか り, また解剖学的に重要と考兄られる胁間動脈を温存し た.

症例 3 では術後一過性の不全麻瘏を認めたが軽快し， 症例 4 では術後再建した右腎動脈が閉塞したが，2 カ月 後右自家腎移植を行い，その後経過は良好であり，全例 通常の社会生活を送っている。

\section{考察およびまとめ}

胸腹部大動脈瘤は文字ど和り，胸部㘧よび腹部大動脈 に及ぶ動脈瘤と解されるが，腎動脈を含む中枢側腹部大 動脈の病変，いわ㠴る上腹部大動脈瘤も同じ範疇の病変 として取り扱われ，その定義に多少の相異があり，Crawford らは，その病型を1978年には五つの型に，1979年 には六つの型に分類し報告している゙が，後者の分類が 妥当であろう。

胸腹部大動脈瘤に対する到達方法は spiral opening 法2)が良好な手術野を得る最良の方法であるが，腹部に 打いては傍腹直筋切開により後腹膜より到達すれば，腹 部内臟を露出しないため操作が容易となり，また術後回 復の面からもより有利と考光られる。血行再建方法は解 剖学的方法 (Etheredge 法, Crawford 法) ならびに非 
表 2 胸腹部大動脈瘤手術症例

\begin{tabular}{|c|c|c|c|c|c|c|c|c|c|c|}
\hline 症 例 & 年齢, & 性 & 成 因 & $\begin{array}{l}\text { 病 } \\
\text { 型 }\end{array}$ & 到 達 法 & 手術手技 & 補助手段 & $\begin{array}{l}\text { 主要分枝再建 } \\
\text { ないし愠存 }\end{array}$ & 対麻癘 & 転 \\
\hline 1 & 57 & 男 & 動脈硬化 & I & $\mathrm{S} / \mathrm{O}$ & 胸腹部大動脈置換 & 一時的 & 腹腔動脈 & $\ominus$ & 5 年 生 \\
\hline 2 & 58 & 男 & 動脈硬化 & III & $\mathrm{S} / \mathrm{O}$ & 胸腹部大動脈置換 & 一時的 & 腹腔動脈 & $\ominus$ & 2 年11力月生 \\
\hline 3 & 55 & 男 & $\begin{array}{l}\text { 動脈硬化 } \\
\text { (解離 III b) }\end{array}$ & N & $\mathrm{S} / \mathrm{O}$ & $\begin{array}{l}\text { 胸部下行大動脈再建 } \\
\text { 未梢側開空術 }\end{array}$ & 一時的 & $\begin{array}{l}\mathrm{T}_{11} \text { 肋間動脈 } \\
\text { 左蜸動脈 }\end{array}$ & $\Theta$ & 1 年 1 力.月生 \\
\hline 4 & 40 & 男 & 動脈硬化 & N & $\mathrm{S} / \mathrm{O}$ & $\begin{array}{l}\text { 胸腹部大動脈置換 } \\
\text { (Etheredge 法) }\end{array}$ & 一時的 & $\begin{array}{l}\text { 腹腔動脈 } \\
\text { 上腸間膜動脈 } \\
\text { 再篎動脈 }\end{array}$ & $\Theta$ & 1 年 1 力月生 \\
\hline 5 & 60 & 男 & 動脈硬化 & III & $\begin{array}{l}\text { (1) } P / L+S \\
\text { (2) } S / O\end{array}$ & $\begin{array}{c}\text { (1)胸部下行大動脈置換 } \\
\text { (2)胸腹部大動脈具換 } \\
\text { (DeBakey 法) }\end{array}$ & $\begin{array}{l}\text { (1)一時的バイ } \\
\text { (2) } \ominus\end{array}$ & $\begin{array}{l}\text { (1) } \ominus \text { 腹腔動脈 } \\
\text { 上腸䦔動脈 } \\
\text { 宁 } \\
\text { 10 肋間動脈 }\end{array}$ & (1) $\Theta$ & 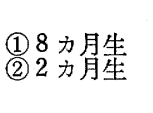 \\
\hline
\end{tabular}

S/O : spinal opening. $\mathrm{P} / \mathrm{L}$ : posterolateral thoracotomy. S : sternotomy

解剖学的方法 (DeBakey 法, Hardy 法) に大別される が，それぞれ一長一短があり，瘤の位置，範囲之内蔵動 脈合併の程度により病変に応じた方法を採用すべきであ る.

血行再建に括ける内臓臓器の虚血は一時的バイパス法 の応用によりとくに問題とはならないが，再建ないしは 温存すべき肋間動脈がはっきり規定できないことが最大 の難点である，II， II ， N 型のごとき広範囲の病変では
二期的手術も考虑すべきであり，また脊䯣虚血の発見に 体性知覚誘発電位のモニターを積極的に応用すべきであ ろう.

文 献 1) Crawford, E.S. et al. : Surgery of the Aorta and Its Body Branches, ed. by Bergen, J.J. and Yao, J.S.T., p. 145, Grune \& Stratton, Inc., New York, 1979. 2) Stoney, R.J. and Wylie, E.D. : Am. J. Surg. 126 : 157, 1973.

\section{3 胸腹部大動脈瘤の外科治療和よび成績の検討}

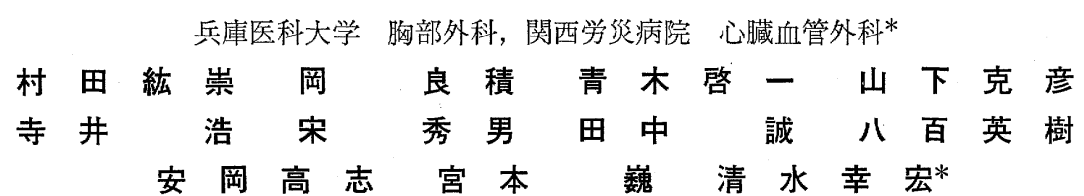

はじめに

横隔膜の上下にまたがり，しばしば腹部主要分枝の起 始部を含む胸腹部大動脈瘤は比較的まれであり，したが ってその外科治療は手技の困難さや術後合併症の多いこ となどからいまだ満足すべき成績とはいえない，昭和 51 年 10 月以来 6 例の胸腹部大動脈瘤を経験したので報告 する.

\section{対 象}

男性 4 例, 女性 2 例で年齢は 32 74 歳, 平均 56 歳であ る (表 1 ). 動脈瘤の成因は動脈硬化性 3 例, 解離性 3 例でらち 1 例は marfan 症候群例である.
手術

補助手段としては症例 2 を除く 5 例に軽度 低体 温法 を，症例 $1 ， 3 ， 4$ では一時的バイパス法を，また症例 4 では冷却した乳酸加リンゲル液による左腎動脈灌流を 行ったまをた最近の症例 6 に和いては脊䯣虚血を予防す る為, 脳脊髄液圧を測定するとともに体性感覚誘発電位 （SEP）を測定した. 大動脈瘤への到達方法は症例 1,2, 3,4 では左側方開胸を腹部正中切開へと連続させた が，5，6では胸骨正中切開に全腹部正中切開を連続さ せた。 術式注 Crawford 法が 3 例, extra anatomic bypass 法が 2 例，DeBakey 法が 1 例である(図 1 ). extra anatomic bypass を行った理由は症例 5 が胸郭成形術後 